DOI https://doi.org/10.32841/2409-1154.2021.50-1.1

\author{
Aghakishiyeva Gulnar Mahammad gizi, \\ PhD student of the Modern Azerbaijani Language Department Baku Slavic University \\ https://orcid.org/0000-0002-0510-1375
}

\title{
FORMS OF DEVELOPMENT OF COLLOQUIAL LANGUAGE
}

Summary. The main purpose of this article is to conduct a comparative analysis of the forms of development of the National (public) language in modern times. It is noted that the literary language is not an artistic language or an artistic language cannot be a literary language. They say that the literary language, which is the most developed form of the national Azerbaijani language, is a broader concept and, like other styles, includes an artistic style - literary language.

Methods used in the article. A comparative analysis of existing publications on this topic was carried out, the experience in this area both at the national and international levels was studied, and the ways of their application in the development of the national Azerbaijani language were indicated.

The novelty of the article. For the first time at the national level, a content analysis of existing publications was carried out, aspects of the differences between the literary language and the artistic language were classified, the regularities of the constant interaction of different branches of the national language - the artistic language, the literary language, dialects and phraseologies, were shown, attention was drawn to their influence on the development and enrichment of the language.

Assessing the attitude of well-known Azerbaijani and foreign linguists to this topic, the author noted that the national language is a synthesis of literary synonyms, neologisms, archaisms and other stylistic devices of the national language.

In conclusion, it is noted that all dialectisms have a history, and in its essence all the subtleties of the people and its history are reflected. It is argued that the vocabulary of the Azerbaijani language consists not only of words used in the literary language.

An important part of the vocabulary of the Azerbaijani language also exists in folk dialects. Words in the dictionary of dialects and phraseologies are also the result of centuriesold processes. Although over time a number of words were removed from the dictionary of the literary language, dialects and phrases have preserved these words for a long time and passed them down from generation to generation. It is noted that in this regard, dialects and phrases of the Azerbaijani language have a rich vocabulary.

Key words: Language, colloquial language, Azerbaijani linguistics, literary language, artistic language, dialect words.

Introduction. Relevance of the topic. Recent studies in the field of linguistics have shown that the literary language, artistic language, dialectism, which are manifestations of the national language, are one of the most difficult problems of linguistics. Opinions about both the literary language and the artistic language and dialectisms do not always coincide.

The main purpose of this article is to conduct a comparative analysis of the forms of development of the National (public) language in modern times. It is noted that the literary language is not an artistic language or an artistic language cannot be a literary language. They say that the literary language, which is the most developed form of the national Azerbaijani language, is a broader concept and, like other styles, includes an artistic style - literary language.

Methods used in the article. A comparative analysis of existing publications on this topic was carried out, the experience in this area both at the national and international levels was studied, and the ways of their application in the development of the national Azerbaijani language were indicated.

The novelty of the article. For the first time at the national level, a content analysis of existing publications was carried out, aspects of the differences between the literary language and the artistic language were classified, the regularities of the constant interaction of different branches of the national language - the artistic language, the literary language, dialects and phraseologies, were shown, attention was drawn to their influence on the development and enrichment of the language.

Review of recent publications on the subject. Though the literary language is a linguistic concept, it remains one of the unsolved problems in linguistics. In short, the concept of literary language is a complex one.

Assessing the attitude of well-known Azerbaijani and foreign linguists to this topic, the author noted that the national language is a synthesis of literary synonyms, neologisms, archaisms and other stylistic devices of the national language.

It has not yet been scientifically proven where the boundary between literary-artistic language and dialect-accent begins and ends. Therefore, most of those who talk about it address this issue from different perspectives, but not in terms of general scientific principles [1, p. 300].

It should be noted that in the past, the notions of literary language, artistic language, literary-artistic language were notclearly explained, thus literary language was understood as the language of belles-lettres and the history of literary language was considered in a restricted sense of poets and writers' creativity, even interpreted as literary-artistic language.

Considering it would be linguistically interesting, let's take a look at the reports and researches conducted on these issues in terms of general and Azerbaijani linguistics.

Generalizing the views on literary language together A. Damirchizade writes: "Some people have recognized literary language as only a written language, did not even thinking about the existence of the spoken literary language. Therefore, they have not gone far beyond the study of the language of written literature, written documents, and finally the language of inscriptions as far as literary language and its development were concerned. This perception has generated misunderstandings according to which "peoples without a written language cannot have a literary language"; or the time of emergence of a country's literary language has been considered to begin from the time when the country has recognized its written language" [2, s. 11]. 
The concept of literary language was sometimes identified with that of the state language, so people have put forward erroneous notions about some people's literary language and their history. Due to the socio-political structure of various periods, the adopted language used in public institutions was considered to be the literary language of people who did not speak that language. For example, the Arabic and Persian, which were officially used in public institutions of Azerbaijan in the Middle Ages, were considered as the literary language of Azerbaijanis [2, s. 15-16].

It should be noted that in the past, the notions of literary language, artistic language, literary-artistic language were not clearly explained, thus literary language was understood as the language of belles-lettres and the history of literary language was considered in a restricted sense of poets and writers' creativity, even interpreted as literary and artistic language.

Some people acknowledged the language of belles-lettres as far as literary language concerned, and therefore the literary language for them was considered in a restricted sense of poets and writers' creativity, and consequently sometimes other fields of literary language were excluded from the study, and the history relating to the scope of the literary language has not been properly studied.

According to $\mathrm{V}$. Vinogradov, the concepts of "literary language" and "language of belles-lettres" were not adequately differentiated. The scope of these concepts has not been defined in terms of different historical periods. Historical forms of interaction between literary language and the language of literary works have not been fully revealed [3, s. 83].

The main feature that distinguishes literary language from artistic language is that it is a type of polished and standardized form of colloquial language, "a language standardized by selection and substitution [3, s. 19].

Thus, it is apparent that the literary language was a language developed based on the colloquial language through the selection and substitution process. "Literary or literary-written language" exists in different forms and types in different historical periods. It is considered a language that has always been developed to some degree, legalized, well-conceived, and more or less obeying the language processing rules [4, s. 107].

A. Damirchizade also mentions that the type, area of application and scope of literary language also influences the definition of criteria. Of course, the substitution and selection process which is vital in the emergence and development of the oral literary language, may not fully coincide with the selection and substation used in the emergence and development of written literary language. Also, the selection and substitution criteria used during the first formation may not be the same as the selection and substitution criteria used in the subsequent development of a long-established literary language [2, s. 17].

The vocabulary is used wholly only in the artistic style of the national literary language. Unlike other styles, all elements of the national language vocabulary can be used here: literary norm and non-literary norm (simple-familiar words and phrases, dialect words), synchronous and diachronic vocabulary (archaisms, historisms), emotional-expressive vocabulary and a wide range of colloquial vocabulary with different patterns, as well as specific lexical units of functional styles and etc. N.A. Baskakov rightly said that "belles-lettres is a laboratory that cultivates and crystallizes synonyms, neologisms, archaisms and other stylistic devices of the national language" [5, s. 25].
It should be noted that along with the artistic speech, literary language, the artistic style is also called literary-artistic language in some cases due to the broadness of its functional capabilities. At the same time, the artistic style contributed to the formation and progress of the national literary language, as well as the study of the stages of historical development. Artistic style has been developed thanks to the individual styles of poets and writers to serve the development and enrichment of the literary language, and provide it with new norms. Thus, A.I. Yefimov evaluates the role of literary style among functional styles as follows: "The language of belleslettres occupies a central place in the system of styles of literary language. It is kind of the nucleus of literary language" [6, s. 65].

Indeed, literary language is a prime example of the colloquial language, the embodiment of its inner potential, which creates wide opportunities for our poets and writers providing a wide range of possibilities of expression for using abundant lexical wordgroups to express their ideas.

The colloquial language manifests itself in various forms. Within the framework of colloquial language, there are figurative, emotional, expressive, common-vulgar words, territorial dialects that contradict the literary language while being considered characteristic of artistic language. Literary language is a well-developed and polished form of the colloquial language based on written norms. Literary language is expressed in written and oral form. Literary language is one of the written branches of artistic language.

Belles-lettres (literary language) which provides the main source of enrichment and development of literary language, has a wider range of expressions than literary language. The application of nonliterary language (slang, jargons, vulgarisms, archaisms, historical words, dialect words, etc.) along with emotional-expressive, figurative expressions in literary language, which is not acceptable in literary language, provides good reason to have for a wider range of expressions than literary language. Poets and writers use the words and expressions that are rarely used by sharpening and honing them so that they take a new shape, in short, masters of word give a new spirit and breath to the word. Thus, these words and expressions when used in artistic language seem to spread their wings in the face of images, becoming figurative, expressive and live. Thus, words are revived and shaped in an aesthetic function when they fall under the control of belles-lettres. Moreover, along with the use of all means of the colloquial language, words and combinations acquire the ability to express new meanings and stylistic patterns in addition to their usual lexical meaning. In his article entitled "Poetry of prose", G. Kazimov writes: "When the words are transformed into characters, a writer becomes more independent and productive within certain limits. The violations of the norms are often observed while writers develop characters' speech in order to create local color and individualization. Dialect pronunciation, dialect words, argotic expressions, the most frequent word reordering are related to the level of cultural and aesthetic requirements of the author towards the character speech [7, s. 14].

Consequently, it may be concluded that an artistic language which on the one hand contradicts the norms of literary language, leads to its enrichment as well. So, colloquial language, literary language and artistic language are always interconnected.

Artistic language provides the main material for revealing the patterns of the colloquial language, literary language, the poets/writer's ability to use words, as well as their aesthetic attitude towards words [7, s. 9]. 
Poets and writers who are considered as creators of literary language are given freedom to use language. What does this freedom entail? Every writer is given the freedom to create new words, use new forms instead of old ones, use new expressions and compositions via colloquial language, to use figurative and emotional language tools such as archaic words, dialect words, etc. However, writers are also required to follow the norms of language, the structure of language. A writer who arbitrarily uses both the elements of literary language and the norms of literary language harms beauty and laws of language. Because writers try harder than linguists to enrich and protect our literary language.

In his article, "On some issues of the Azerbaijani literary-artistic language", famous critic and literary scholar M. Jafar mentions that literary language is first of all generalized, to put it more simply, a standardized language that entails all positive elements and traditions, as well as innovations of colloquial language to bring together all the power of colloquial language [8, p. 29].

In his abovementioned article, the literary scholar explains the reasons why the inability to correctly define the boundaries of literary and artistic language occurs. He notes that a group of writers and poets in their works considered colloquial and artistic language as their native language standing far from the literary language. They alienated literary language. Therefore, they have used non-literary language tools in their works, which are far from the norms of literary language, and they feel proud to compare their language with the lifeless, lean language of a few inexperienced writers who mostly writes in the language of books and newspapers. Of course, this group of artists is justly proud of the fact that they don't write in callous language of books. However, relying on this opinion, no one can justify them because they are proud of violating the norms of literary language. A group of writers and linguists furthermore consider school grammar close to themselves, with a discriminatory attitude towards the living language. Therefore, this group of writers and linguists regard those who adhere to the principles of living colloquial language in their writings, but sometimes do not follow the norms of literary language, as writers who are lagging in terms of language culture. On the contrary, they consider those whose language is far from colloquial language, which is close to the language of books, insensitive, unemotional, also strictly adheres to school grammar, as the writers with the highest linguistic culture [8, p. 31].

In our view, the opinion shared by both groups of writers and linguists cannot be justified, given that artistic language is a living spoken language consisting of a synthesis of colloquial and literary language, as well as one of the sources that foster literary language. Literary works which enjoys a wide readership are written in accordance with peoples tastes and wishes. So, literary works must be written in a language that people can easily understand. The belles-lettres, where a writer can skillfully use rich treasure of the colloquial language while creating a piece of art, has the highest linguistic culture. At the same time, writers who use elements of language that are far from the elements of artistic language, but only meet the norms of literary language, must take into account that the language of literary works that are far from the living colloquial language will sound simple, boring, and engage fewer readers. Thus, every literary work must be written in a language that meets the norms of literary language, along with the expression and composition of colloquial, figurative and emotional language. The conclusion is that literary language and artistic language are constantly developing and enriching each other.

Although artistic language is originally derived from the spoken language of the working masses, it differs significantly from the latter, because when writers use spoken language, they throw out all the random, temporary, transient and rough to spell words from that rich but unorganized vocabulary, keeping only the words that are close to colloquial language and spirit. Writers have constantly honed and improved artistic language [9, p. 224].

It is belles-lettres, writers and masters of words who keep language alive, beautifies, revives and refreshes it.

The language of fiction is an important and advanced part of our common literary language, because the language that writers and poets use plays a critical role in the development of literary language, either in the past or at the present times. Therefore, special attention should be paid to its proper development [9, s. 243].

In his article entitled "Language and style", M. Arif notes that when the issue of the formation of the Azerbaijani literary language emerged, there were two directions of language development.

Proponents of the first direction shared the opinion that literary language could not be intended for mass audience, they believed that it was only intended for a handful of educated aristocrats, so there was no need to try to simplify literary language; the more difficult and challenging a literary language is, the more influential it will be. Those who wanted to use the Azerbaijani literary language in this way were alienated not only from the language, history and culture of the people in general, they were deprived of patriotic honor, did not believe in the strength and ability of the people and did not protect their independence. Those who wanted to promote the Azerbaijani literary language in this direction were not well-informed about the language, history and culture of the people in general, they were deprived of patriotic honor, did not believe in the power and ability of the people and did not protect their independence.

Proponents of the second direction considered literary language as the language of the people, saying that this language is for everyone, everyone should read and write, and should be closely involved in the development of society. Literary language should be as simple as everyone should understand it. Those who held that view were visionary people, who believed in the power of the people and properly evaluated the development of history [10, p. 219].

The Azerbaijani literary language is the highest form of the colloquial Azerbaijani language, and this language was not formed all of a sudden. It is a product of centuries and one the most perfect means of communication that has, over the centuries, served Azerbaijanis with dignity. We know well that the most polished and perfect examples in the history of our literary language emerged in artistic speech, and that literary quality is most strongly expressed in literary language, in short, artistic style underlies the history of our literary language. The development of realism in artistic language, the increase of national character and sometimes its overdevelopment reached such a point that suddenly linguists emerged who freely put artistic language with its independent character against literary language with its literary norms. Fortunately, however, hopes of these philological innovators quickly dashed. The traditional idea has survived: artistic language is a branch of standardized literary language, its strongest branch, and it is the most sensitive area that regulates development trends of literary language. [10, s. 230].

Artistic style denotes literary language, because when we talk about artistic style, we mean linguistic features of literary works. It 
should be noted that the language of any literary work is the result of the writer's use of colloquial language. Summarizing the views expressed in linguistics on artistic style, A. Gurbanov notes that there are differing views among linguists concerning this issue.

1. Some linguists do not agree that artistic style is functional. They consider it as language of literary works, not of style.

2. Other linguists recognize the concept of "artistic style" calling literary works not as whole, but only author speeches expressed in them. They consider character speech nonliterary. What is wrong is some linguists approach the issue of character speech from a biased point of view. As we know a character speech in a literary work is not the same as spoken language. While creating a character speech, writers and poets conduct strong language and stylistic operation, embellishing it with artistic quality [11, p. 29].

According to A. Gurbanov, artistic language is not isolated from literary language, colloquial language, and in its broadest sense, from colloquial language; it is a broadest, polished, re-developed branch and effective area of this language [12, p. 22].

Speaking about the freedom of artistic style and its wide spectrum of possibilities, A. Gurbanov explains: "Artistic style implies the use of approximately every word group that exists in a language. Any notion in a language is at the disposal of artistic style. In artistic style, words related to art, profession or dialect are used to individualize the speech of various characters or any stylistic point." [13, p. 450].

It should be noted that artistic style, which we call artistic language, artistic speech, belles-lettres, is one of the functional styles that has the widest potential of literary language, that is close to colloquial language with national, simple, clear, pure, concise, complete, harmonious, figurative, emotional, expressive features. Due to these features, artistic language in general differs from language and literary language.

Outstanding Azerbaijani poet S. Vurgun considered artistic language as a leading branch of the literary language; therefore, he regarded the development of artistic language as the development of literary language in general. So, S. Vurgun believed that struggle for artistic language is an integral part of struggle for literary language, which increases the importance of the poet's views on artistic language. In the struggle for a new, modern artistic language, the poet's first slogan was simplicity, national character who said: "Great, insightful thoughts and feelings should be communicated to people in simple language" $[14$, p. 240].

$\mathrm{He}$ also shared his views on literary language, associating the Azerbaijani literary language with the development of the Azerbaijani people, its cultural level. S. Vurgun wrote: "Our literary language is developing through the words and expressions used by workers, collective farmers and laborers, as well as through our classical written literature, broad and rich folk literature, as well as various international words and expressions" [14, p. 259].

Literary works embraces the history, traditions, morality and psychology, desires and ideals of an entire nation.

Thus, artistic language is one of the authoritative sources in terms of studying colloquial language, as well as any features and qualities of its important branch - literary language, and revealing, comparing and analyzing its characteristics and patterns [10, p. 38]

Regarding literary language A. Damirchizade writes: "The style of literary language, which was initially formed, frequently updated, with its colorful variants, is artistic style which is considered to be more popular. Artistic style is also denoted as artistic language, and in that sense, the two terms are almost synonymous" [2, p. 31].
Unlike other styles of literary language, artistic language - artistic style is a language that establishes the most effective connection, builds "bridges" between spoken language and literary language. Colloquial language, colloquial expressions are mostly expressed in literary language through literary works. Artistic language reflects national traditions, preserves its essence, promotes and cherishes it for centuries setting an example for future generations [14, p. 112-113].

There is abundant figurative means of artistic language. One of such means is dialect words brought to the literary language by poets and writers from dialects and accents.

Conclusion. Summarizing the above, we see that dialectics have a history in itself, and in its essence it reflects all the subtleties of the people and its history.

Dialects are words that cherish historical features. As we learn dialects, we learn about the people and their history. As is well known, the vocabulary of the Azerbaijani language consists not only of words used in the literary language, but an important part of the vocabulary of our language exists in accents. The words in the vocabulary of our dialects and accents are also the product of many centuries. While several words disappear from the vocabulary of a literary language over certain period of time, national dialects and accents retain and keep those words for a long period of time. From this point of view, dialects and accents of the Azerbaijani language have a rich vocabulary.

Dialect words that were brought to the artistic language by poets and writers for certain stylistic purposes are such an inexhaustible treasure of our literary language that literary language is constantly nourished and enriched by this treasure. It is no coincidence that dialect words are one of the richest and inexhaustible sources in terms of studying the history of our language, analyzing the process of historical development of any grammatical feature or category, compiling of explanatory dictionaries, creating new terminology glossaries, determining principles of orthographies and norms of literary language. Of course, in this enrichment process, artistic language plays a transitional role, because dialect words do not transmit directly into the literary language, but through literary works and artistic language. "Dialect vocabulary is such a permanent base that it primarily contributes to artistic style of literary language" [15, p. 216].

In general, conducting research on dialect words, relationship between literary language and artistic language, dialects and, at the same time, colloquial language, remains one of the major challenges facing our linguistics.

"The constant coexistence of dialects with literary language ensures mutual enrichment of their vocabulary" [16, p. 43].

On the one hand, it enriches the vocabulary by transmitting words from dialects to literary language, and on the other hand, it compresses them by transmitting words from literary language to dialects, and thus dialects and literary language interact with each other.

It is necessary to use the dialect words of the region and territory where the events in the narrative taking place or the region the fictional characters come from in order to make the language of the literary work more natural and real.

It is impossible to avoid dialect words in artistic language. As branches of the colloquial language, dialects and accents provide rich resources for making language more colorful and imaginative, individualizing speech of characters, and enriching literary language. However, it is inadmissible to contaminate the language 
by overusing dialects or to turn artistic language into regional language [7, p. 18].

Indeed, on the one hand, it enriches the vocabulary by passing words from dialects to literary language, and on the other hand, it compresses them by passing words from literary language to dialects, and thus dialects and literary language interact with each other.

Excessive use of lexical borrowings, archaisms, dialect words, emotional and expressive words, onomastic units and other units of language in literary works can do more harm than good to the whole literary work. Instead, purposeful use of these words will make the literary work more valueable, and its language more vivid and natural [17, p. 114].

Dialect words uses by poets and writers for various stylistic purposes in artistic language, which is an integral part of literary language, play a crucial role in enriching our literary language through its internal possibilities, along with making artistic language vivid, natural, figurative and emotional.

Dialect words are symbols of understanding colloquial language. There is a tradition of using them in belles-lettres. In literary works, the expressive and emotional patterns of words are perceived through dialect words. Writers and poets also used dialect words for describing ancient life and creating a landscape $[18$, p. 164; 19].

We can conclude from the above mentioned that literary language is not an artistic language, and vice versa. Literary language, which is the highest developed form of the colloquial Azerbaijani language, is a much broader concept and, like other styles, encompass an artistic style - the literary language. The branches of the colloquial language, that is literary language, artistic language, dialects and accents continue to interact, develop and enrich one another.

\section{References:}

1. Xəlilov Q.Q. Azərbaycan romanının inkişaf tarixindən, Bakı: Elm, $1973,350 \mathrm{~s}$.

2. Dəmirçizadə Ә.M. Azərbaycan dilinin üslubiyyatı, Bakı: Azərtədrisnəşr, 1962, $270 \mathrm{s.}$

3. Виноградов В.В. Проблемы литературных языков и закономерностей их образования и развития. М., 1967. 598 с.

4. Axundov A.A. Ümumi dilçilik, Bakı: "Şərq-Qərb", 2006. 280 s.

5. Әfəndiyeva T.Ә. Azərbaycan dilinin leksik üslubiyyatı, Bakı: Elm və tahsil, 2012. $352 \mathrm{~s}$.

6. Ефимов А.И. О роли национальной художественной литературы в развитии русского литературного языка. $360 \mathrm{c}$.

7. Kazımov Q.Ş. Seçilmiş əsərləri, 10 cilddə, IVcild, Bakı: Nurlan, 2009. $528 \mathrm{~s}$.

8. M.Cəfər. Seçilmiş əsərləri, I cild. Bakı: Çinar-Çap, 2003. 360 s.

9. M.Arif. Әdəbi-tənqidi məqalələr, Bak1: Azərnəşr, 1958. $444 \mathrm{~s}$.

10. Hacıyev T.İ. Şeirimiz, nəsrimiz, ədəbi dilimiz, Bakı: Yazıçı, 1990. 359 s.

11. Qurbanov A.M. Bədii mətnin linqvistik təhlili, Bakı: Nurlan, $2005.476 \mathrm{~s}$.

12. Qurbanov A.M. Dil və üslub, Bakı: APU, 1992. $46 \mathrm{~s}$.

13. Qurbanov A.M. Müasir Azərbaycan ədəbi dili, 2 cilddə, I cild, Bak1: Nurlan, 2003. $450 \mathrm{~s}$.
14. Seyidov Y.M. Әsərləri: 15 cilddə, VIII cild, Bakı: Bakı Universiteti, 2008. $678 \mathrm{~s}$.

15. Məmmədov M.B. Filoji düşüncələr, Bakı: Nurlan 2005. $360 \mathrm{~s}$.

16. Məmmədova N.H. Rəsul Rza və sərbəst şerin dili məsələsi, Bakı: Elm, 2004. $262 \mathrm{~s}$.

17. Cəfərov A.G. Nəbi Xəzrinin poetik dili, Bakı: Elm və təhsil, 2012. $143 \mathrm{~s}$.

18. Hüseynova H.E. Mir Cəlalın bədii əsərlərinin linqvopoetik xüsusiyyətləri. I cild. Bakı: ADPU, 2018. $429 \mathrm{~s}$.

19. Hüseynova M.N. Müasir Azərbaycan dili: aşıq və el şairlərinin yaradıcıllğının dil və üslub xüsusiyyətlər, Bakı: Avropa, 2018. $423 \mathrm{~s}$.

Агакішіева Г. Форми розвитку загальнонаціональної мови

Анотація. Основна мета написання статті - провести порівняльний аналіз форм розвитку загальнонародної (загальнонаціональної) мови в сучасний період. Відзначається, що літературна мова не є художньою мовою або художня мова не може бути літературною мовою. 3'ясовано, що літературна мова, яка є найбільш розвинутою формою загальнонаціональної азербайджанської мови, являє собою більш широке поняття і поряд 3 іншими стилями включає художній стиль.

Методи, використані в статті. Проведений порівняльний аналіз існуючих публікацій з даної теми, було вивчено досвід в цій сфері як на національному, так і на міжнародному рівнях, вказано шляхи його застосування в процесі розвитку загальнонаціональної азербайджанської мови.

Новизна статті. Уперше на національному рівні проведено контент-аналіз наявних публікацій, класифіковані аспекти відмінностей літературної мови від художньої, показані закономірності постійної взаємодії різних гілок загальнонаціональної мови - художньої мови, літературної мови, діалектів і фразеології, звертається увага на їхній вплив на розвиток і збагачення мови.

Оцінюючи ставлення до даної теми відомих азербайджанських і зарубіжних лінгвістів, автор зазначив, що загальнонаціональна мова являє собою синтез літературних синонімів, неологізмів, архаїзмів та інших стилістичних прийомів національної мови.

На завершення зазначається, що у всіх діалектизмів $\epsilon$ історія, а в їхній суті відображені всі тонкощі народу i його історії. Стверджується, що словниковий запас азербайджанської мови складається не тільки зі слів, які використовуються в літературній мові. Важлива частина словникового запасу азербайджанської мови існує і в народних діалектах. Слова в словнику діалектів і фразеології також $\epsilon$ результатом багатовікових процесів. Хоча $з$ часом зі словника літературної мови був видалений ряд слів, діалекти і фрази довгий час зберігали ці слова і передавали їх із покоління в покоління. Відзначається, що у зв'язку з цим діалекти і фразеологізми азербайджанської мови мають багатий словниковий ресурс.

Ключові слова: мова, ідеї, загальнонаціональна мова, азербайджанська лінгвістика, літературна мова, художня мова, діалектизм. 